\title{
NITROGEN DYNAMICS IN A SOIL-SUGAR CANE SYSTEM
} \author{
de Castro Navarro'; Marisa de Cássia Piccolo ${ }^{5,8}$; Fábio Augusto Meira Cássaro ${ }^{1,7}$ \\ ${ }^{1}$ Lab. de Física do Solo - USP/CENA, C.P. 96 - CEP: 13400-970 - Piracicaba, SP. \\ ${ }_{3}^{2}$ Depto. de Ciências Exatas - USP/ESALQ, C.P. 9 - CEP: 13418-970 - Piracicaba, SP. \\ ${ }^{3}$ Depto. de Produção Vegetal - USP/ESALQ. \\ ${ }_{5}^{4} L a b$. de Isótopos Estáveis - USP/CENA. \\ ${ }^{5}$ Lab. de Biogeoquímica - USP/CENA. \\ ${ }_{7}^{6}$ Bolsista FAPESP. \\ ${ }^{7}$ Bolsista CAPES. \\ ${ }^{8}$ Bolsista CNPq. \\ *Corresponding author<lctimm@carpa.ciagri.usp.br>
}

Júlio César Martins de Oliveira ${ }^{1,6} ;$ Klaus Reichardt $^{1,2,8} ;$ Osny O.S. Bacchi ${ }^{1,8} ;$ Luis Carlos Timm $^{1,6 *}$; Durval Dourado-Neto ${ }^{3,8}$; Paulo César Ocheuse Trivelin ${ }^{4,8}$; Tânia Toyomi Tominaga ${ }^{1,6}$; Roberta

\begin{abstract}
Results of an organic matter management experiment of a sugar cane crop are reported for the first cropping year. Sugar cane was planted in October 1997, and labeled with a ${ }^{15} \mathrm{~N}$ fertilizer pulse to study the fate of organic matter in the soil-plant system. A nitrogen balance is presented, partitioning the system in plant components (stalk, tip and straw), soil components (five soil organic matter fractions) and evaluating leaching losses. The ${ }^{15} \mathrm{~N}$ label permitted to determine, at the end of the growing season, amounts of nitrogen derived from the fertilizer, present in the above mentioned compartments.

Key words: fertilizer, nitrogen, ${ }^{15} \mathrm{~N}$ label, soil, sugar cane
\end{abstract}

\section{DINÂMICA DO NITROGÊNIO EM UM SISTEMA SOLO-CANA-DE-AÇÚCAR}

\begin{abstract}
RESUMO: São apresentados resultados de um experimento sobre matéria orgânica em cultura de cana-deaçúcar, relativos ao primeiro ano (cana planta). A cultura foi instalada em outubro de 1997 e marcada com um pulso de fertilizante ${ }^{15} \mathrm{~N}$, para estudar o destino da matéria orgânica no sistema solo-planta. É apresentado um balanço de nitrogênio, subdividindo o sistema em componentes de planta (colmo, ponteiro e palha), componentes de solo (cinco frações de matéria orgânica do solo) e estimando perdas por lixiviação. $\mathrm{O}{ }^{15} \mathrm{~N}$ permitiu a determinação das quantidades de nitrogênio provenientes do fertilizante nos compartimentos acima mencionados, no final do ciclo da cultura.
\end{abstract}

Palavras-chave: fertilizante, nitrogênio, ${ }^{15} \mathrm{~N}$, solo, cana-de-açúcar

\section{INTRODUCTION}

Sugar cane is the most important crop for the sugar industry, Brazil having today 5 million hectares cultivated with this crop. The understanding of nitrogen dynamics in this soil-plant system will, therefore, contribute for the establishment and improvement of management practices, mainly now when the traditional practice of straw burning before harvest will be substituted by machine harvest, which leaves on the soil surface a considerable amount of trash, corresponding to an organic fertilization. Abramo Filho et al. (1993), Trivelin et al. (1995;1996) present a detailed study on sugar cane trash dry-matter and its nutrient content, specially in relation to nitrogen.

Sugar cane belongs to the family of the grasses, presents a sigmoid growth curve (Brzesowsky, 1986) with a pronounced phytomass production in response to nitrogen availability (Bolton \& Brown, 1980), and being a $\mathrm{C}_{4}$ cycle plant it presents twice as much dry matter per unit weight of leaf nitrogen, as compared to $\mathrm{C}_{3}$ cycle plants (Black et al., 1978). Reports of Lima Júnior (1982);
Sampaio et al. (1984), and Bittencourt et al. (1986), indicate, however, that the potential of converting fertilizer $\mathrm{N}$ into phytomass is very variable and relatively low for the first crop cycle. This fact is attributed to non symbiotic nitrogen fixation (Döbereiner et al., 1972), soil N mineralization; plant residue mineralization, and the use of the nitrogen of the stalk that originated the new plant. Lima et al. (1987) and Urquiaga et al. (1992) report that sugar cane grown in Brazil receive, in general, low nitrogen rates, in the range 60 to $120 \mathrm{~kg} \mathrm{ha}^{-1}$, having stalk yields of 65 to $70 \mathrm{~kg} \mathrm{ha}^{-1}$ of $\mathrm{N}$, and the whole plant accumulates 100 to $120 \mathrm{~kg} \mathrm{ha}^{-1}$ of $\mathrm{N}$. This indicates that the non symbiotic nitrogen fixation might play an important role as a nitrogen source, since soils cultivated with sugar cane for long periods do not suffer significant yield reduction. Although gradual and slow, organic matter mineralization is of significant importance to the crop, since it is through this process that part of the needed nutrients reach the plant. Sampaio et al. (1995) evaluated the soil supply capacity and the fertilizer response of sugar cane, and concluded that the main $\mathrm{N}$ source for the crop is the native soil organic 
matter and the maintenance of crop residues on the field.

This study has the intention to collaborate for a better understanding of the fate of a $\mathrm{N}$ fertilizer application, after one year, on a newly established sugar cane crop, in different soil and plant compartments, using the ${ }^{15} \mathrm{~N}$ label, in a similar way as reported by Vanlauve et al. (1998).

\section{MATERIAL AND METHODS}

In a sugar cane field variety SP80-3280 medium/ late of fifteen rows $40 \mathrm{~m}$ long, spaced $1.4 \mathrm{~m}$, totalizing 924 $\mathrm{m}^{2}$ (Rhodic Kandiudalf called "Terra Roxa Estruturada"), located in Piracicaba, São Paulo State, Brazil $\left(22^{\circ} 42^{\prime}\right.$ S; $47^{\circ} 38^{\prime} \mathrm{W}$ ), eight plots $R_{i}$ were chosen along the three central cane rows, to apply the ${ }^{15} \mathrm{~N}$ fertilizer pulse. Figure 1 presents a simplified scheme of the experimental arrangement, showing three central sugar cane rows, for ${ }^{15} \mathrm{~N}$ labeling, which received ammonium sulfate with 11.7 $\%$ a.e. ${ }^{15} \mathrm{~N}$, at a $\mathrm{N}$ rate of $63 \mathrm{~kg} \mathrm{ha}^{-1}$, and $44.4 \mathrm{~kg} \mathrm{ha}^{-1}$ of $\mathrm{P}$ and $83 \mathrm{~kg} \mathrm{ha}^{-1}$ of $\mathrm{K}$, all at planting (November 1997). These 8 plots, $4 \mathrm{~m}$ long each, represent replicates, since no treatment was tested. The rest of the field received the same fertilization, however, without label. At harvest (October 1998), the fate of this ${ }^{15} \mathrm{~N}$ pulse was studied in several plant and soil compartments.

For each replicate, 3 composite soil samples were take at the depths $0-0.15 ; 0.15-0.3$ and $0.3-0.5 \mathrm{~m}$,

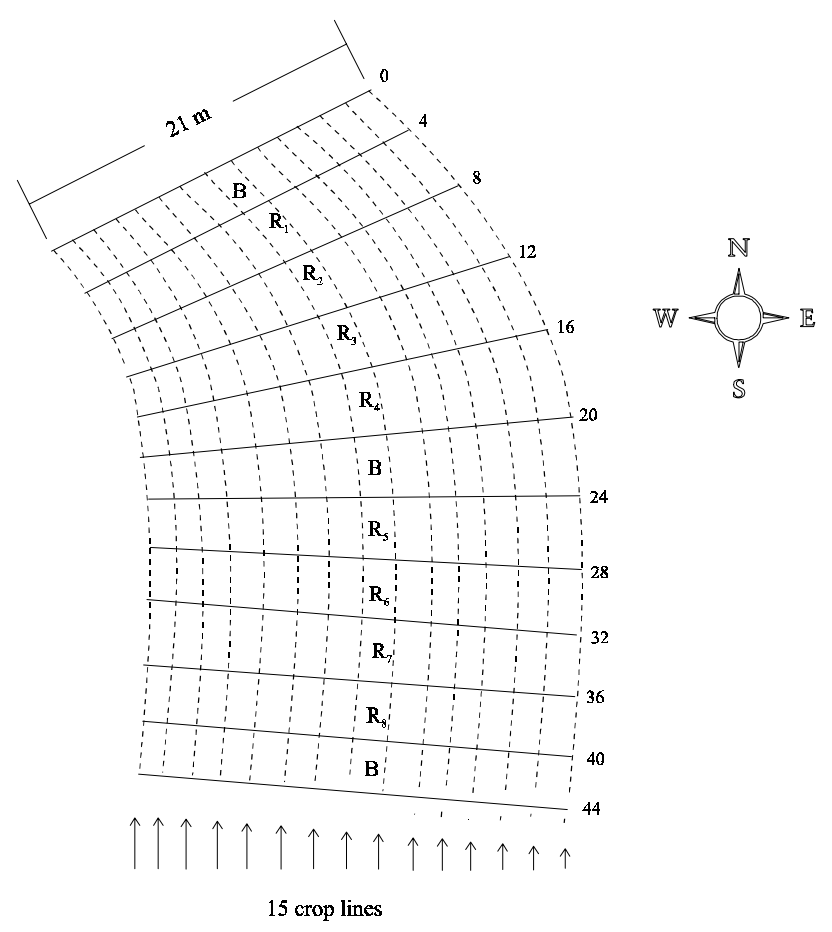

Figure 1 - Experimental design, indicating the 8 plots (replicates) placed within the sugar cane field. $R=$ replicates; $\mathrm{B}=$ border. processed according to Anderson \& Ingram (1993) and Feller (1978), for soil organic matter (SOM) fractionation. By means of successive dry and wet sievings at 2000, 200 and $50 \mu \mathrm{m}$, OM was separated in organic, mineral and organo-mineral fractions. Air dry soil samples $(<2 \mathrm{~mm})$ were separated in five fractions by wet sieving: 1. light $\mathrm{SOM}_{1}$, floating in water $(200-2000 \mu \mathrm{m})$, essentially organic, mostly plant debris; 2 . heavy $\mathrm{SOM}_{2}(200-2000$ $\mu \mathrm{m})$ related to sand, and therefore considered mineral; 3 . $\mathrm{SOM}_{3}(50-200 \mu \mathrm{m})$ related to silt, considered organomineral; 4. heavy $\mathrm{SOM}_{4}(0-50 \mu \mathrm{m})$ related to the clay precipitated by centrifugation, also organo-mineral; 5 . solution $\mathrm{SOM}_{5}(0-50 \mu \mathrm{m})$ also related to clay, remaining in solution after centrifugation, and also organo-mineral. Non fractionated samples were also used for SOM determination to check the efficiency of the procedure.

Plants were always sampled meter by meter, four composite samples per replicate, collecting leaf $3^{+}$samples for ${ }^{15} \mathrm{~N}$ analysis, in February, May, and at harvest in October 1998, when crop yield was evaluated measuring the number of canes, weight of canes, weight of trash and weight of green leafs (cane tips). After drying at $65^{\circ} \mathrm{C}$ the fresh weights were transformed into dry matter (DM) yield data. Total nitrogen and ${ }^{15} \mathrm{~N}$ enrichment were measured with a mass spectrometer ANCA-SL, Europe Scientific, Crewe, UK.

Nitrogen derived from fertilizer (Ndff), for any compartment ${ }^{1}$ in the system was calculated from:

Ndff $=\frac{\left(\text { atom } \%{ }^{15} \text { Nexcess of compartmert }\right)}{\left(\text { atom } \%{ }^{15} \text { Nexcess of fertilizer }\right)}$

Total amounts of nitrogen in any compartment of the plant or soil of the system, derived from fertilizer or residue (TNdff, $\mathrm{kg} \mathrm{ha}^{-1}$ ), were calculated according to:

TNdff $=$ Ndff.$($ DMyield of compartment).(total $\mathrm{N}$ content of compartment, \%)/100

in which DM is expressed in $\mathrm{kg} \mathrm{ha}^{-1}$.

Nitrogen leaching was estimated measuring the concentration $\mathrm{C}_{\mathrm{N}}$ of total $\mathrm{N}$, and the enrichment in ${ }^{15} \mathrm{~N}$ of the soil solution, using porous cup extractors, one per replicate, installed at the depth of $1.0 \mathrm{~m}$. The total amount of leached $\mathrm{N}$ was estimated as follows:

$$
\mathrm{Q}_{\mathrm{N}}=\int_{\mathrm{ti}}^{\mathrm{tf}} \mathrm{q}_{\mathrm{w}} \cdot \mathrm{C}_{\mathrm{N}} \cdot \mathrm{dt}
$$

Where $t$ is the time in days and $q_{w}$ is the soil water flux density at $z=1.0 \mathrm{~m}$, estimated from Darcy's equation, in $\mathrm{mm}$. day ${ }^{-1}$. With the ${ }^{15} \mathrm{~N}$ enrichment of the soil solution, $Q_{N}$ values were transformed into leached nitrogen derived from fertilizer, using equations 1 and 2 .

\footnotetext{
${ }^{1}$ Compartment: plant stalk (cane), straw, tip, rhizome, root]; soil $\left(\mathrm{SOM}_{1}, \mathrm{SOM}_{2}, \ldots . \mathrm{SOM}_{5}\right)$; fertilizer; leacheate; other losses. In the case of sugar cane, the sum of straw (old dry leaves) and tips (green leaves and apical gem) is called trash.
} 


\section{RESULTS AND DISCUSSION}

Some chemical characteristics of the soil along the transect, for soil samples collected before planting (October 1997) are presented in TABLE $1\left(\mathrm{pH}\right.$ in $\mathrm{CaCl}_{2}, \mathrm{OM}, \mathrm{P}, \mathrm{K}$, $\mathrm{Ca}$ and $\mathrm{Mg}$ ). The analysis of these data indicated that the chosen area is relatively isotropic for crop production. There was no significant difference between replicates.

Figure 2 shows the values of ${ }^{15} \mathrm{~N}$ atom \% excess, measured for leaf $3^{+}$, for the 8 replicates, which received labeled fertilizer in October 1997, for three dates: 10 February 1998, 13 May 1998, and at harvest, 15 October 1998. This data give an idea about the rate of fertilizer $\mathrm{N}$ uptake, during the first year of the sugar cane crop, and also of the variability of the data. In terms of average, Figure 3 shows the evolution of the ${ }^{15} \mathrm{~N}$ label in the plant during the first year. It can be seen that the uptake of

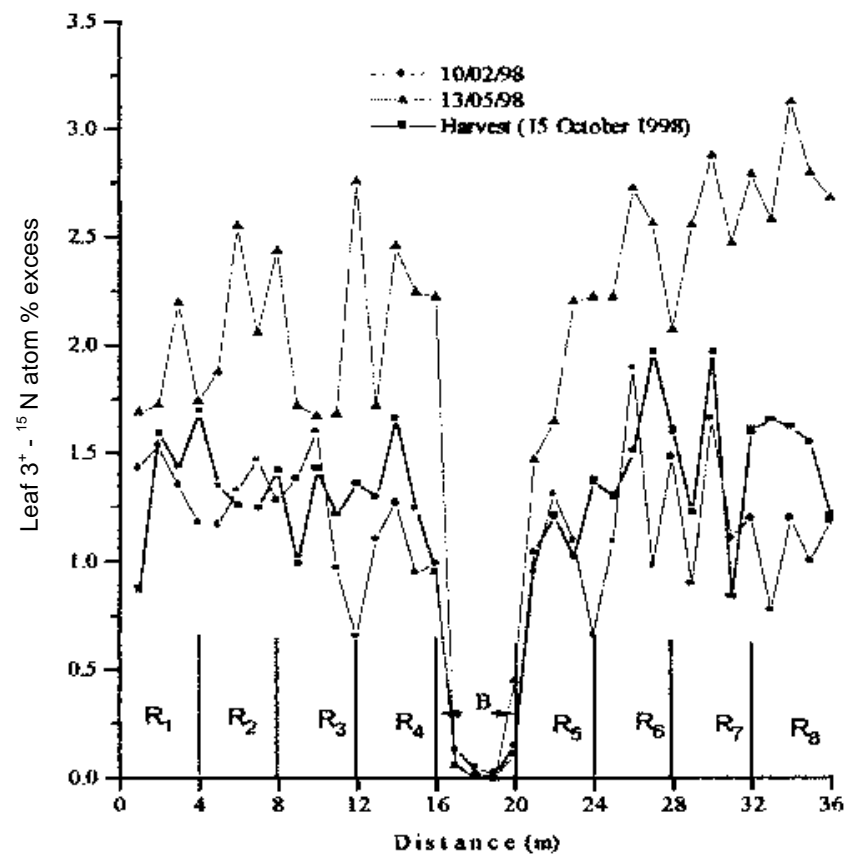

Figure 2 - Distribution of ${ }^{15} \mathrm{~N}$ atom \% excess in leaf $3^{+}$for strips 3 and 4 during 1998. fertilizer $\mathrm{N}$ increased up to May, and that, thereafter, the increasingly uptake of soil $\mathrm{N}$ decreased the ${ }^{15} \mathrm{~N}$ content in the leafs.

At harvest (October 1998) plant and soil were sampled in more detail. Figure 4 gives an overview of the label distribution in the three chosen plant compartments [stalk, tip and straw] along the eight replicates. TABLE 2 presents the overall $\mathrm{N}$ balance, in $\mathrm{kg} \mathrm{ha}^{-1}$ of $\mathrm{N}$, taking into account soil and plant compartments. Soil fractionation data present high coefficients of variation (CV), mainly in the case of the mineral fraction $\mathrm{SOM}_{2}$. Plant $\mathrm{N}$ variability was, in general, smaller than soil $\mathrm{N}$ variability. It is important to note that the soil used in this experiment is very rich in $\mathrm{N}$, presenting on the average $7660 \mathrm{~kg} \mathrm{ha}^{-1}$. Soil fertilization with $\mathrm{N}$ is, however, very important even at the relatively low fertilization rate of $63 \mathrm{~kg} \mathrm{ha}^{-1}$, since the crop does respond to these applications (Lima et al., 1987).

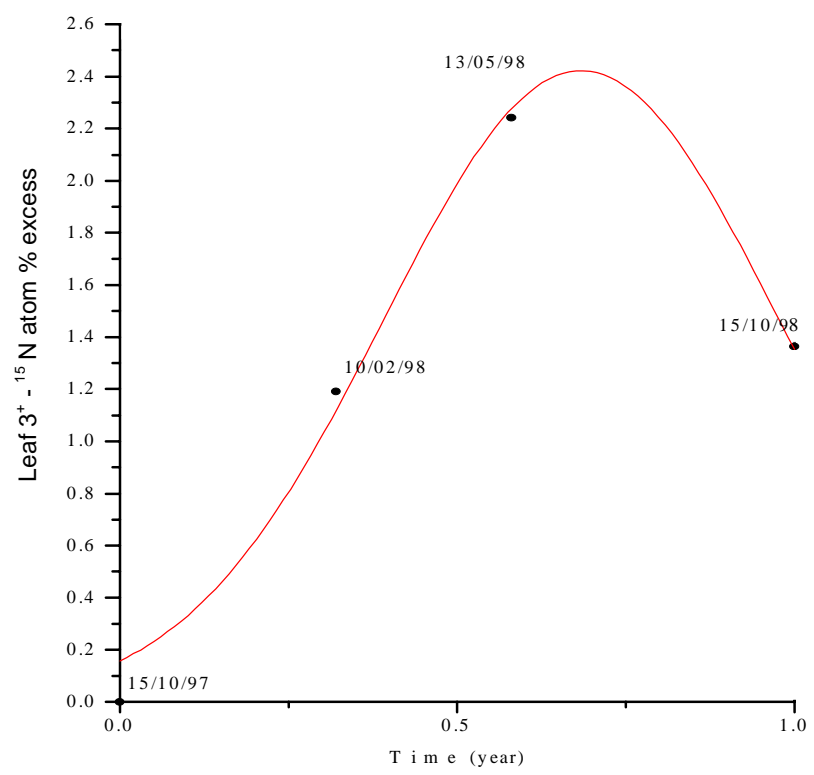

Figure 3 - Average evolution of ${ }^{15} \mathrm{~N}$ atom \% in leaf $3^{+}$during the first cropping year. Time zero $=$ planting, time $1=$ harvest .

TABLE 1 - Soil (Rhodic Kandiudalf) chemical characteristics of the sugar cane field.

\begin{tabular}{|c|c|c|c|c|c|c|}
\hline Replicate & $\mathrm{pH}$ in $\mathrm{CaCl}_{2}$ & OM & $\mathrm{P}$ & $\mathrm{K}$ & $\mathrm{Ca}$ & $\mathrm{Mg}$ \\
\hline & & $\mathrm{g} \mathrm{dm}^{-3}$ & $\mathrm{mg} \mathrm{dm^{-3 }}$ & \multicolumn{3}{|c|}{ - $\mathrm{mmol}_{\mathrm{c}} \mathrm{dm}^{3} \mathrm{~m}$} \\
\hline 1 & 5.1 & 26.0 & 35.8 & 4.3 & 59.5 & 15.8 \\
\hline 2 & 5.0 & 22.3 & 26.5 & 3.1 & 62.0 & 15.8 \\
\hline 3 & 4.9 & 22.8 & 32.5 & 3.0 & 58.5 & 14.8 \\
\hline 4 & 5.0 & 23.0 & 51.8 & 3.2 & 73.0 & 15.8 \\
\hline 5 & 4.8 & 24.5 & 31.3 & 3.7 & 66.0 & 15.3 \\
\hline 6 & 4.7 & 25.5 & 22.8 & 3.6 & 65.0 & 15.0 \\
\hline 7 & 4.7 & 23.5 & 19.5 & 3.0 & 58.3 & 13.8 \\
\hline 8 & 4.7 & 23.0 & 20.8 & 2.8 & 63.5 & 15.3 \\
\hline Mean & 4.9 & 23.8 & 30.1 & 3.3 & 63.2 & 15.2 \\
\hline SD & 0.16 & 1.35 & 10.53 & 0.50 & 4.91 & 0.68 \\
\hline CV (\%) & 3.3 & 5.7 & 34.9 & 14.8 & 7.8 & 4.5 \\
\hline
\end{tabular}


TABLE 3 presents the balance of the labeled nitrogen, applied at the rate of $63 \mathrm{~kg} \mathrm{ha}^{-1}$ with a ${ }^{15} \mathrm{~N}$ enrichment of 11.7 atom \% excess. This is a commonly applied $\mathrm{N}$ rate for this type of soil. Due to all variabilities which contribute in the calculation of these final values of Ndff, in three of the eight replicates we found more than $63 \mathrm{~kg} \mathrm{ha}^{-1}$ of $\mathrm{N}$ in plant and soil $\left(\mathrm{R}_{3}, \mathrm{R}_{4}\right.$ and $\left.\mathrm{R}_{6}\right)$. On the average, however, the balance seems reasonable. The line NOC (TABLE 3) represents the amounts of $\mathrm{N}$ needed to close the balance. NOC includes also the $50-100 \mathrm{~cm}$ soil layer and the rhizome, which were not sampled. However, part of the $\mathrm{N}$ of the rhizome and of the root system are in the $\mathrm{SOM}_{\mathrm{i}}\left(\mathrm{SOM}_{4}>\mathrm{SOM}_{5}>\mathrm{SOM}_{3}>\mathrm{SOM}_{1}\right)$ fractions. The light organic fraction $\mathrm{SOM}_{1}$ presents the least amount of
${ }^{15} \mathrm{~N}$, indicating that very little of the fresh organic matter was present in the soil after harvest. $\mathrm{SOM}_{2}$ did not present ${ }^{15} \mathrm{~N}$, as expected since it is constituted mostly of sand. $\mathrm{SOM}_{3}$ and $\mathrm{SOM}_{5}$, the first related to silt and the second to solution after clay centrifugation, present similar amounts of ${ }^{15} \mathrm{~N}$, however about one third less than $\mathrm{SOM}_{4}$, related to the clay precipitated by centrifugation. There is very little data in the literature, for tropical soils, to be compared with the SOM data of TABLE 3. Feller \& Beare (1997) discuss some of these, and state that the "organoclay complex" that corresponds to $\mathrm{SOM}_{5}$, has a predominance of amorphous $\mathrm{OM}$, which acts cementing the clay matrix, being, therefore, a very strongly bound form of OM.

TABLE 2 - Distribution of total nitrogen content in all compartments, for the first year (October 1997 - October 1998).

\begin{tabular}{|c|c|c|c|c|c|c|c|c|c|c|c|c|}
\hline \multicolumn{2}{|l|}{ Compartment } & $\mathrm{R}_{1}$ & $\mathrm{R}_{2}$ & $\mathrm{R}_{3}$ & $\mathrm{R}_{4}$ & $\mathrm{R}_{5}$ & $\mathrm{R}_{6}$ & $\mathrm{R}_{7}$ & $\mathrm{R}_{8}$ & mean & SD & CV \% \\
\hline \multirow[t]{3}{*}{ Fertilizer } & & 63 & 63 & 63 & 63 & 63 & 63 & 63 & 63 & 63 & & \\
\hline & \multicolumn{12}{|c|}{ - } \\
\hline & $\mathrm{SOM}_{1}$ & 89 & 40 & 88 & 65 & 74 & 52 & 79 & 63 & 68.8 & 17.2 & 25.0 \\
\hline Soil & $\mathrm{SOM}_{2}$ & 9 & 15 & 39 & 6 & 20 & 4 & 0 & 12 & 13.1 & 12.2 & 93.1 \\
\hline \multirow[t]{3}{*}{$(0-0.5 \mathrm{~m})$} & $\mathrm{SOM}_{3}$ & 1592 & 1565 & 1680 & 1216 & 1575 & 1343 & 1084 & 1272 & 1415.9 & 215.3 & 15.2 \\
\hline & $\mathrm{SOM}_{4}$ & 6241 & 4211 & 4269 & 5306 & 4549 & 4261 & 4866 & 4215 & 4739.8 & 720.4 & 15.2 \\
\hline & $\mathrm{SOM}_{5}$ & 921 & 2101 & 1446 & 1968 & 1328 & 1390 & 1018 & 1208 & 1422.5 & 419.1 & 29.5 \\
\hline \multirow[t]{2}{*}{ Total } & & 8855 & 7932 & 7522 & 8561 & 7546 & 7050 & 7047 & 6770 & 7660.4 & 745.1 & 9.7 \\
\hline & Stalk & 144 & 119 & 151 & 133 & 126 & 148 & 105 & 119 & 130.6 & 16.3 & 12.4 \\
\hline Plant & Tip & 79 & 77 & 75 & 80 & 77 & 74 & 73 & 69 & 75.5 & 3.5 & 4.7 \\
\hline (Shoot) & Straw & 51 & 52 & 47 & 48 & 42 & 44 & 42 & 43 & 46.1 & 4.0 & 8.6 \\
\hline Total & & 274 & 248 & 273 & 261 & 245 & 266 & 220 & 231 & 252.3 & 19.8 & 7.8 \\
\hline $\begin{array}{l}\text { Leached } \\
(100 \mathrm{~cm})\end{array}$ & & 1 & 1 & 1 & 1 & 1 & 1 & 1 & 1 & 1 & 0 & 0 \\
\hline
\end{tabular}

TABLE 3 - Distribution of the nitrogen derived from fertilizer in all compartments, for the first year (October 1997 - October 1998).

\begin{tabular}{|c|c|c|c|c|c|c|c|c|c|c|c|c|}
\hline \multicolumn{2}{|l|}{ Compartment } & $\mathrm{R}_{1}$ & $\mathrm{R}_{2}$ & $\mathrm{R}_{3}$ & $\mathrm{R}_{4}$ & $\mathrm{R}_{5}$ & $\mathrm{R}_{6}$ & $\mathrm{R}_{7}$ & $\mathrm{R}_{8}$ & $\begin{array}{c}\text { overall } \\
\text { mean }\end{array}$ & SD & CV \% \\
\hline \multirow[t]{3}{*}{ Fertilizer (FN) } & & 63 & 63 & 63 & 63 & 63 & 63 & 63 & 63 & 63 & 0 & 0 \\
\hline & \multicolumn{12}{|c|}{ 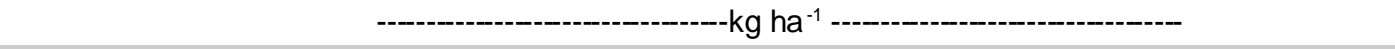 } \\
\hline & $\mathrm{SOM}_{1}$ & 2.4 & 1.4 & 3 & 4 & 1.7 & 1.6 & 2 & 2.9 & 2.4 & 0.9 & 37.2 \\
\hline Soil & $\mathrm{SOM}_{2}$ & 0 & 0 & 0 & 0 & 0 & 0 & 0 & 0 & 0.0 & 0.0 & 0.0 \\
\hline \multirow[t]{3}{*}{$(0-0.5 m)$} & $\mathrm{SOM}_{3}$ & 2.8 & 3.6 & 4.1 & 4.8 & 3.4 & 3 & 2.5 & 3.9 & 3.5 & 0.8 & 21.4 \\
\hline & $\mathrm{SOM}_{4}$ & 10.9 & 9.5 & 11.2 & 18.1 & 9.6 & 9.4 & 10 & 11.6 & 11.3 & 2.9 & 25.5 \\
\hline & $\mathrm{SOM}_{5}$ & 3.4 & 4.6 & 3.5 & 5.9 & 2 & 2.6 & 1.5 & 2.4 & 3.2 & 1.4 & 44.8 \\
\hline \multirow[t]{2}{*}{ Total (S) } & & 19.5 & 19.1 & 21.8 & 32.8 & 16.7 & 16.6 & 16 & 20.8 & 20.4 & 5.4 & 26.6 \\
\hline & Stalk & 22.1 & 16.1 & 28.6 & 22.8 & 19.5 & 29.6 & 18.7 & 20.9 & 22.3 & 4.7 & 21.1 \\
\hline Plant & Tip & 9.4 & 8.2 & 8.2 & 9 & 7.6 & 10 & 8.8 & 8.9 & 8.8 & 0.8 & 8.6 \\
\hline (Shoot) & Straw & 9.1 & 8.2 & 9.8 & 8.8 & 7.4 & 10.2 & 9 & 8.3 & 8.9 & 0.9 & 10.1 \\
\hline \multicolumn{2}{|l|}{ Total (P) } & 40.6 & 32.5 & 46.6 & 40.6 & 34.5 & 49.8 & 36.5 & 38.1 & 39.9 & 5.9 & 14.8 \\
\hline \multicolumn{2}{|l|}{$\mathrm{NOCa}$} & 2.9 & 11.4 & -5.4 & -10.3 & 11.8 & -3.4 & 10.5 & 4.1 & 2.7 & 8.4 & 310.9 \\
\hline \multicolumn{2}{|l|}{ Leached $(100 \mathrm{~cm})$} & 0 & 0 & 0 & 0 & 0 & 0 & 0 & 0 & 0 & 0 & 0 \\
\hline
\end{tabular}

aNOC: Nitrogen in other compartments: soil (50-100 cm); part of rhizome; other losses. This line was used to close the balance according to: $N O C=F_{N}-(S+P)$ 


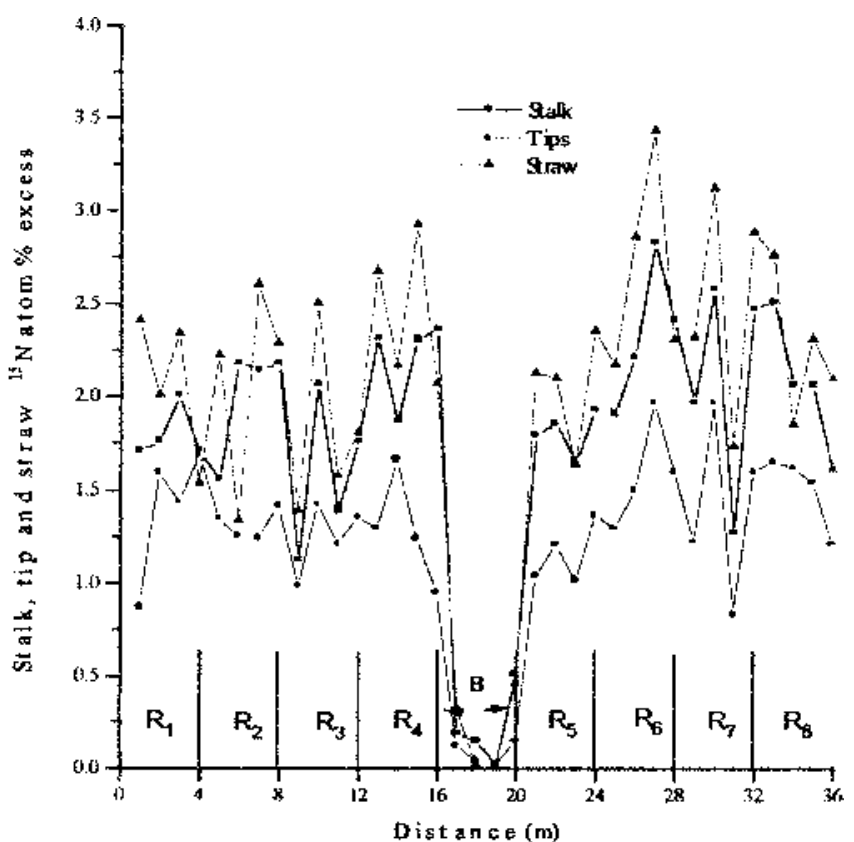

Figura 4 - Distribution of ${ }^{15} \mathrm{~N}$ enrichment in stalk, tip (leaf $3^{+}$) and straw at harvest (October 1998).

Figure 5 gives an average overview of the distribution of the nitrogen in the sampled compartments. The cane shoot presents $252.3 \mathrm{~kg} \mathrm{ha}^{-1}$, of which 39.9 are derived from the applied fertilizer, and 212.4 come from the soil, and possibly from non-symbiotic nitrogen fixation, as suggested by Urquiaga et al. (1992). The soil pool is large, corresponding to $7660.4 \mathrm{~kg} \mathrm{ha}^{-1}$, of which 20.4 were added through fertilization. This addition corresponds to $0.27 \%$, which after one year (at harvest) presented a very low enrichment of 0.038 atom excess ${ }^{15} \mathrm{~N}$, making it more difficult to follow its fate for the next cropping season. As already said, the soil fractionation in five compartments indicates that most of the soil $\mathrm{N}$ derived from the fertilizer is in the fraction $\mathrm{SOM}_{4}\left(11.3 \mathrm{~kg} \mathrm{ha}^{-1}\right)$ that is the fraction obtained by wet seaving in the range 0 to $50 \mu \mathrm{m}$. Fraction $\mathrm{SOM}_{1}\left(2.4 \mathrm{~kg} \mathrm{ha}^{-1}\right)$, the floating fraction in the range 200 to $2000 \mu \mathrm{m}$, is not so expressive as it should be, since it includes fresh organic matter, mainly from roots and rhizome. It presented, however, the highest ${ }^{15} \mathrm{~N}$ enrichment of all fractions: 0.443 atom excess.

The efficiency of the plant in using fertilizer $\mathrm{N}$ was extremely high, of the order of $60 \%$. According to Trivelin et al. (1996) the efficiency seldomly overcomes $40 \%$. Our high efficiency is due to the form of application, which was in solution, well distributed at the base of each row meter, when plants were sprouting and, therefore, with a significantly well developed root system. One day after label application the crop received a rain of $13.5 \mathrm{~mm}$, which helped its homogenization, absorption, and was not sufficient to leach $\mathrm{N}$ to greater depths.

Nitrogen in other not measured compartments NOC, shown in TABLE 3 , had a very low mean, not significantly different from zero, and presented, therefore,

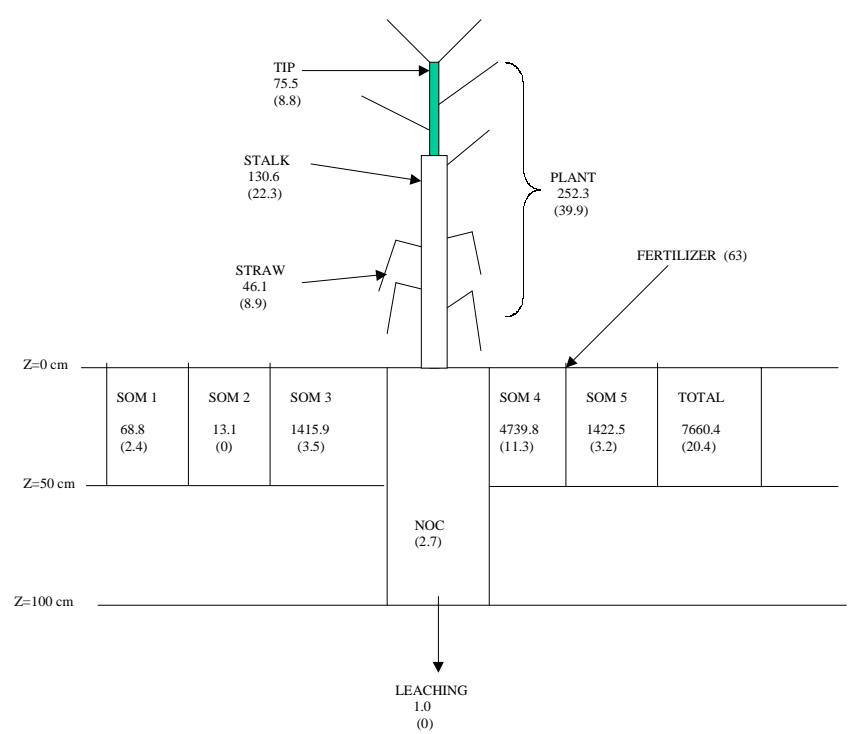

Figure 5 - Schematic average $\mathrm{N}$ balance at harvest (October 1998). Numbers without bracketts correspond to total $\mathrm{N}$ and numbers between bracketts to $\mathrm{N}$ derived from fertilizer. SOM: soil organic matter

NOC: soil $(50-100 \mathrm{~cm})+$ part of rhizome + other losses

an extremely high $\mathrm{CV}$, which has no scientific meaning. It is a result of the variabilities of the $\mathrm{N}$ data in all other measured compartments. Leaching was not measurable, which is also an exception since in many other situations it can reach values of the order of $15 \mathrm{~kg} \mathrm{ha}^{-1}$ of total soil $\mathrm{N}$, with little contribution from the fertilizer $\left(3.0 \mathrm{~kg} \mathrm{ha}^{-1}\right)$, as reported by Reichardt et al., (1982).

\section{ACKNOWLEDGEMENTS}

To FAPESP, S.P., Brazil, Research Contract 97/ 10327-2, to CNPq and IAEA, Vienna, Austria, Research Contract BRA-9031, for financial support.

\section{REFERENCES}

ABRAMO FILHO, J.; MATSUOKA, S.; SPERANDIO, M.L.; RODRIGUES, R.C.D.; MARCHETI, L.L. Resíduo da colheita mecanizada de cana crua. Álcool \& Açúcar, n.67, p.23-25, 1993.

ANDERSON, J.M.; INGRAM, J.S.I (Ed.) Tropical soil biology and fertility: a handbook of methods. 2.ed. Wallingford: $C A B$ International, 1993.

BITTENCOURT, V.C.; FAGANELLO, B.F.; SALATA, J.C. Eficiência da adubação nitrogenada em cana-de-açúcar (planta). STAB - Açúcar, Álcool e Sub-Produtos, v.5, p.25-29, 1986.

BLACK, E.C.; BROWN, R.C.; MOORE, R.C. Plant photosynthesis. In: DOBEREEINER, J.; BURRIS, R.H.; HOLLAENDER, A. (Ed.) Limitations and potentials for biological nitrogen fixation in the tropics. New York: Plenum, 1978. p.95-110.

BOLTON, J.K.; BROWN, R.H. Photosynthesis of grass species differing in carbon dioxide fixation pathways. V. Response of Panicum maximum, Panicum milioides and tallfescue (Festuca arundinacea) to nitrogen nutrition. Plant Physiology, v.66, p.97-100, 1980. 
BRZESOWSKY, W.J. Factors affecting sugarcane: 2. crop growth rate. Agriculture International World Crops, v.38, p.30-35, 1986.

DÖBEREINER, J.; DAY, J.M.; DART, P.J. Nitrogenase activity in the rhizosphere of sugar cane and some other tropical grasses. Plant and Soil, v.37, p.191-196, 1972.

FELLER, C. Une méthode de fractionement granulometrique de la matiére organic des sols. Applicacion anx sols tropicaux a textures grossiéres, trés pandres em humus. Cahiers ORSTOM, Série Pédologie, v.17, p.339-346, 1978.

FELLER, C.; BEARE, M.H. Physical control of soil organic matter dynamics in the tropics. Geoderma, v.79, p.69-116, 1997.

LIMA JÚNIOR, M.A. Nitrogen nutrition of sugar cane in N.E. Brasil. Saskatoon, 1982. 172p. Thesis (Doctor) - University of Saskatchewan.

LIMA, E.; BODDEY, R.M.; DÖBEREINER, J. Quantification of biological nitrogen fixation associated with sugar cane using $a^{15} \mathrm{~N}$ aided nitrogen balance. Soil Biology and Biochemistry, v.19, p.165-170, 1987.

REICHARDT, K.; LIBARDI, P.L.; URQUIAGA, S.C. The fate of fertilizer nitrogen in soil-plant systems with emphasis on the tropics. Proceedings of a IAEA Symposium IAEA- SM- 263/ 36, p.277-289, 1982.

SAMPAIO, E.V.B.S.; SALCEDO, I.H.; BETTANY, J. Dinâmica de nutrientes em cana-de-açúcar: I. Eficiência na utilização de uréia $\left({ }^{15} \mathrm{~N}\right)$ em aplicação única ou parcelada. Pesquisa Agropecuária Brasileira, v.19, p.943-949, 1984.
SAMPAIO, E.V.B.S.; SALCEDO, I.H.; SILVA, V.M.; ALVES, G.D. Capacidade de suprimento de nitrogênio e resposta à fertilização de vinte solos de Pernambuco. Revista Brasileira de Ciência do Solo, v.19, p.269-279, 1995.

TRIVELIN, P.C.O.; RODRIGUES, J.C.S.; VICTORIA, R.L. Utilização por soqueira de cana-de-açúcar de início de safra do nitrogênio da aquamônia- ${ }^{15} \mathrm{~N}$ e uréia- ${ }^{15} \mathrm{~N}$ aplicado ao solo em complemento à vinhaça. Pesquisa Agropecuária Brasileira, v.31, p.89-99, 1996.

TRIVELIN, P.C.O.; VICTORIA, R.L.; RODRIGUES, J.C.S. Aproveitamento por soqueira de cana-de-açúcar de final de safra do nitrogênio da aquamônia- ${ }^{15} \mathrm{~N}$ e uréia- ${ }^{15} \mathrm{~N}$ aplicado ao solo em complemento à vinhaça. Pesquisa Agropecuária Brasileira, v.30, p.1375-1385, 1995.

URQUIAGA, S.; CRUZ, K.H.S.; BODDEY, R.M. Contribution of nitrogen fixation to sugar cane: Nitrogen-15 and nitrogen balance estimates. Soil Science Society of America Journal, v.56, p.105-114, 1992.

VANLAUWE, B.; SANGINGA, N.; MERCKX, R. Soil organic matter dynamics after addition of nitrogen-15-labeled Leucaena and Dactyladenia residues. Soil Science Society of America Journal, v.62, p.461-466, 1998.

$\overline{\text { Received March }}$ 22, 2000 